\title{
Phenotype and genotype of patients with disorder of sex development due to $5 \alpha$-reductase deficiency
}

\author{
Vu Chi Dung ${ }^{1 *}$, Bui Phuong Thao ${ }^{1}$, Nguyen Ngoc Khanh ${ }^{1}$, Can Thi Bich Ngoc ${ }^{1}$, Maki Fukami ${ }^{2}$ \\ From 8th APPES Biennial Scientific Meeting \\ Darwin, Australia. 29 October - 1 November 2014
}

A rare form of the 46,XY disorders of sex development (DSD), $5 \alpha$-reductase deficiency was first described in patients with pseudovaginal perineoscrotal hypospadias, microphallus, and cryptorchid testes in 1974 by Imperato. This undervirilization in the male is due to an alteration in the $5 \alpha$-reductase type 2 gene (SRD5A2), which encodes for $5 \alpha$ - reductase activity. Our registry of 750 patients with DSD showed no definitive diagnosis in $80 \%$ of cases with $46, \mathrm{XY}$ DSD. Our aim is to identify mutations in SRD5A2 gene and to describe phenotype of detected mutative cases. Mutation analysis was performed for genomic DNA extracted from WBC of 10 patients with 46,XY DSD using PCR and direct sequencing. We identified mutations of SRD5A2 gene in two cases. The first case presented with isolated micropenis at birth, two palpable testes in the normal scrotum. Pelvic ultrasound showed no ovaries and uterus, karyotype was $46, \mathrm{XY}$ and SRY was positive. Serum FSH level was $2.4 \mathrm{UI} / \mathrm{L} ; \mathrm{LH}$ level was $0.9 \mathrm{UI} / \mathrm{L}$ and testosterone level was $0.4 \mathrm{nmol} / \mathrm{l}$ at 8 years of age. A homozygous missense mutation (p.R237G) was identified in the SRD5A2 gene. The second case presented with microphaslus, penoscrotal hypospadias, gonad bilateral in labioscrotal folds. No uterus and ovaries were found by pelvic ultrasound. Karyotype was $46, \mathrm{XY}$ and SRY was positive. A novel homozygous missense mutation (c.659C $>\mathrm{T}$; p. S220L) was identified in the SRD5A2 gene. Mutation analysis of SRD5A2 gene helps to make definitive diagnosis for patients with 46,XY DSD.

\footnotetext{
Authors' details

${ }^{1}$ Department of Endocrinology, Metabolism and Genetics. National Hospital of Pediatrics, Hanoi, Vietnam. ${ }^{2}$ National Research Institute for Child Health and Development, Department of Molecular Endocrinology, Tokyo, Japan.

'Department of Endocrinology, Metabolism and Genetics. National Hospital of Pediatrics, Hanoi, Vietnam

Full list of author information is available at the end of the article
}

Published: 28 April 2015

doi:10.1186/1687-9856-2015-S1-P112

Cite this article as: Dung et al.: Phenotype and genotype of patients with disorder of sex development due to $5 \alpha$-reductase deficiency. International Journal of Pediatric Endocrinology 2015 2015(Suppl 1):P112.
Submit your next manuscript to BioMed Central and take full advantage of:

- Convenient online submission

- Thorough peer review

- No space constraints or color figure charges

- Immediate publication on acceptance

- Inclusion in PubMed, CAS, Scopus and Google Scholar

- Research which is freely available for redistribution

Submit your manuscript at www.biomedcentral.com/submit

\section{() Biomed Central}

C Biomed Central

(c) 2015 Dung et al; licensee BioMed Central Ltd. This is an Open Access article distributed under the terms of the Creative Commons Attribution License (http://creativecommons.org/licenses/by/4.0), which permits unrestricted use, distribution, and reproduction in any medium, provided the original work is properly cited. The Creative Commons Public Domain Dedication waiver (http:// creativecommons.org/publicdomain/zero/1.0/) applies to the data made available in this article, unless otherwise stated. 